\title{
Palang Pintu Kereta Api Otomatis Berbasis Data Global Positioning System (GPS)
}

\author{
Lukas B. Setyawan ${ }^{1}$, Gunawan Dewantoro ${ }^{2}$, Mario Augustino Ivan D. B. ${ }^{3}$ \\ Program Studi Teknik Elektro, \\ Fakultas Teknik Elektronika dan Komputer, \\ Universitas Kristen Satya Wacana, Salatiga \\ 1lukas.setyawan@staff.uksw.edu, ${ }^{2}$ gunawan.dewantoro@staff.uksw.edu, \\ 3ivandwinanda.id@gmail.com
}

\begin{abstract}
Ringkasan
Sistem pengontrol buka tutup palang pintu pada perlintasan kereta api sangat diperlukan untuk menghindari terjadinya kecelakaan karena kelalaian faktor manusia. Apabila kereta api akan melewati perlintasan kereta api dan mendekati perlintasan dalam jarak sekitar $500 \mathrm{~m}$ maka palang pintu akan otomatis tertutup. Palang pintu akan kembali terbuka setelah kereta api lewat menjauhi perlintasan. Sistem pengontrol yang diletakkan di gerbong kereta berkomunikasi dengan palang pintu di perlintasan menggunakan frekuensi radio dengan frekuensi $433 \mathrm{MHz}$. Untuk mengetahui jarak kereta api dengan perlintasan digunakan modul GPS APM 2.5 NEO 6M. Hasil pengujian menunjukkan pada saat kereta api mendekat ke perlintasan dalam jarak 595m palang pintu akan menutup. Setelah kereta api meninggalkan perlintasan dalam jarak $300 \mathrm{~m}$ maka palang pintu akan membuka.
\end{abstract}

Kata kunci: palang pintu kereta api, Global Positioning System, frekuensi radio

\section{Pendahuluan}

Sistem buka tutup palang pintu di perlintasan kereta api selama ini dilakukan secara manual, yaitu diperlukan seorang penjaga palang pintu untuk melakukan proses buka tutup palang. Apabila ada kereta api yang akan melewati perlintasan maka penjaga palang pintu mendapat sinyal bahwa ada kereta api yang akan lewat kemudian dilakukan penutupan palang. Setelah kereta api melewati perlintasan maka penjaga palang pintu akan melakukan pembukaan palang pintu. Pada saat penjaga palang pintu melakukan kelalaian dengan mengabaikan sinyal pemberitahuan bahwa kereta api akan melewati perlintasan maka mengakibatkan kecelakaan karena palang pintu tidak tertutup pada saat kereta api melintas. Dengan adanya sistem pengontrol palang pintu otomatis yang tidak memerlukan keberadaan seorang penjaga palang pintu maka terjadinya kecelakaan di perlintasan kereta api bisa dihindarkan [1][2]. Sistem ini secara otomatis akan melakukan proses penutupan palang pintu pada saat kereta api mendekati perlintasan dan setelah kereta api melewati perlintasan maka palang pintu akan membuka secara otomatis.

Pembahasan dimulai dengan penjelasan sistem pengontrol palang pintu meliputi proses kerja sistem, sistem mekanik, sistem perangkat keras, dan sistem perangkat lunak. Kemudian dilanjutkan dengan hasil pengujian dan diakhiri dengan kesimpulan. 


\section{Sistem Pengontrol Palang Pintu}

Sistem pengontrol palang pintu ini terdiri dari dua bagian. Bagian utama adalah Modul Master yang diletakkan di dalam gerbong kereta, terdiri dari Modul GPS, Modul Arduino Uno R3, dan Modul Pemancar. Bagian kedua adalah Modul slave yang diletakkan di perlintasan kereta, terdiri dari Modul Penerima, Modul Arduino Uno R3, serta sistem mekanik penggerak buka tutup palang. Modul GPS yang digunakan adalah Modul GPS APM 2.5 NEO 6M. Modul Pemancar dan Modul Penerima menggunakan Modul $433 \mathrm{MHz}$ Radio Telemetry Kit. Prototipe sistem mekanik penggerak buka tutup palang menggunakan motor DC $12 \mathrm{~V}$.

Konfigurasi sistem pengontrol palang pintu diperlihatkan oleh Gambar 1.

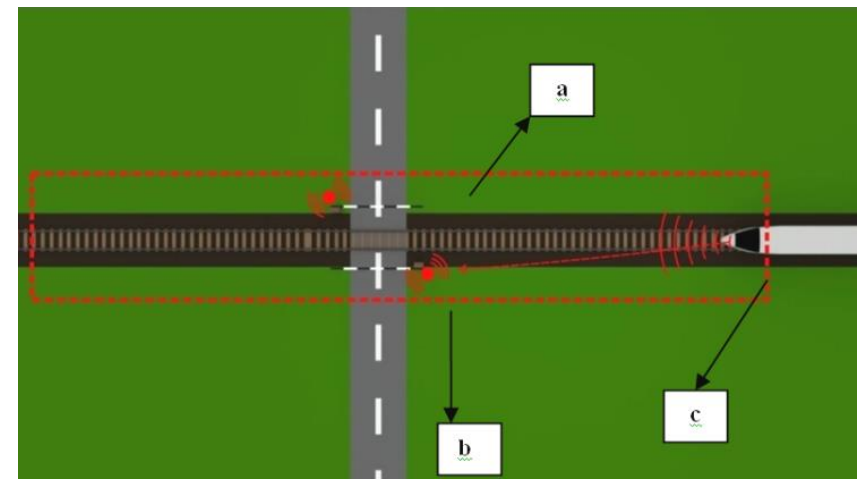

Keterangan :

a. Rentang daerah koordinat perlintasan

b. Modul Slave (Berada di perlintasan)

c. Modul Master (Berada di gerbong kereta)

Gambar 1. Konfigurasi sistem pengontrol palang pintu

\subsection{Proses Kerja Sistem}

Setiap perlintasan yang akan dilewati oleh rute kereta api disimpan koordinatnya di dalam sistem. Jarak kereta api terhadap perlintasan dapat diketahui dengan menghitung jarak antara koordinat perlintasan yang sudah disimpan di memori dengan data koordinat yang diperoleh dari GPS yang terletak di gerbong kereta [3]. Pada saat kereta api mendekati perlintasan dalam jarak 500m maka Modul Master akan mengirimkan sinyal perintah melalui frekuensi radio ke Modul Slave di perlintasan agar menutup palang pintu di perlintasan. Modul Slave akan menguji apakah sinyal perintah ditujukan untuk dirinya. Apabila sinyal perintah ditujukan ke alamat sesuai dengan alamat perlintasan maka palang pintu segera ditutup. Setelah kereta api menjauhi perlintasan dalam jarak sekitar 300m maka Modul Master akan mengirim sinyal perintah ke Modul Slave untuk membuka palang pintu. Proses yang sama akan terjadi setiap kereta api melewati perlintasan. Bagan kotak sistem diperlihatkan pada Gambar 2. 


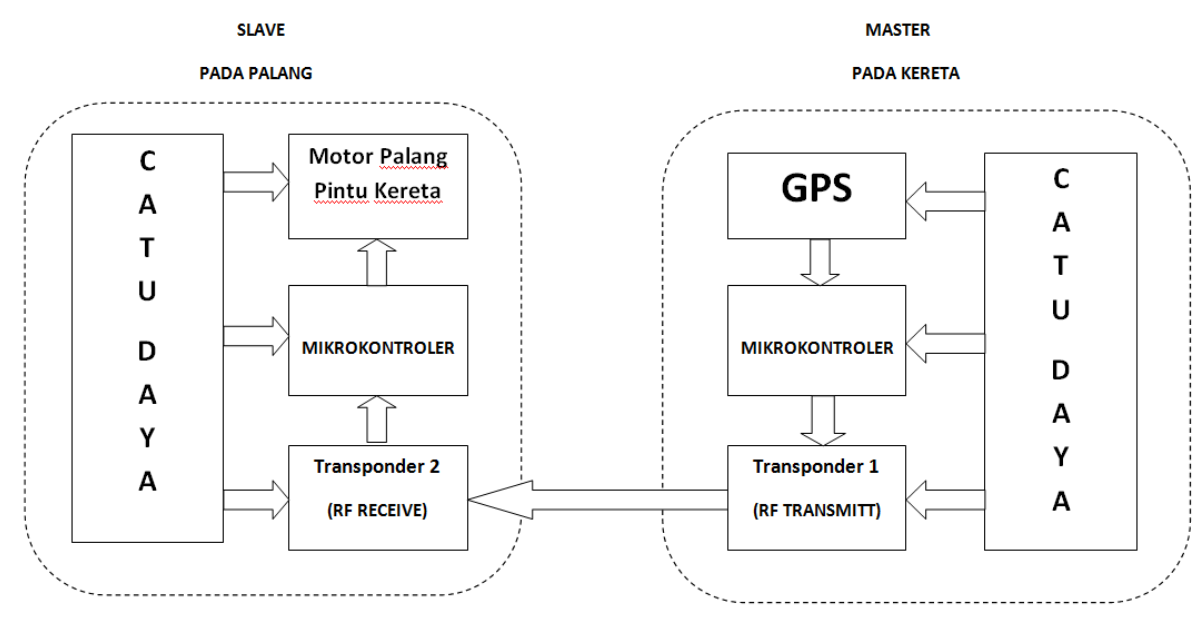

Gambar 2. Bagan kotak sistem

\subsection{Prototipe Sistem Mekanik}

Prototipe sistem mekanik palang pintu tersusun dari kerangka kayu tripleks, motor DC, dan Modul Penggerak Motor. Sketsa sistem mekanik ditunjukkan oleh Gambar 3. Realisasi prototipe mekanik palang pintu diperlihatkan pada Gambar 4.

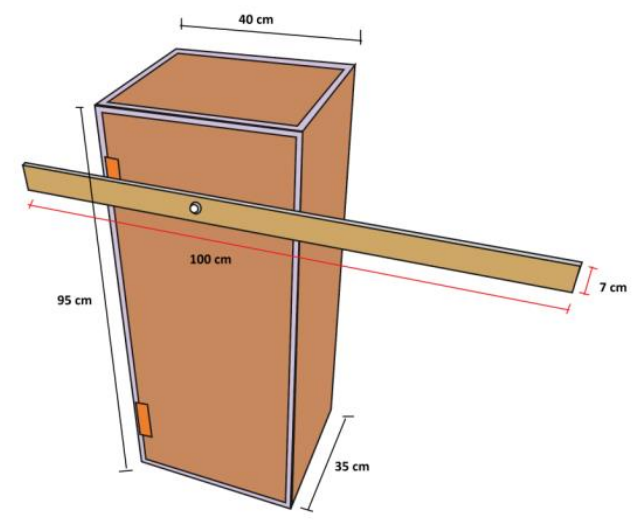

Gambar 3. Sketsa prototipe mekanik palang

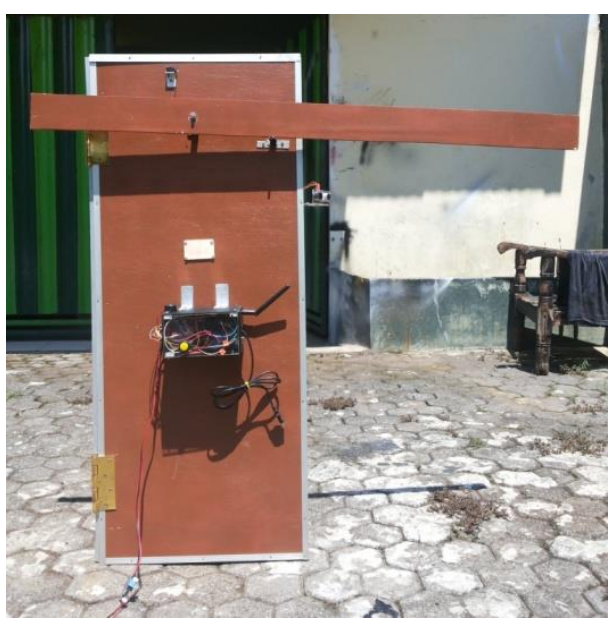

Gambar 4. Realisasi prototipe mekanik palang 
Skema Modul Penggerak Motor DC oleh Gambar 5. Sedangkan gambar Modul Penggerak Motor DC diperlihatkan pada Gambar 6.

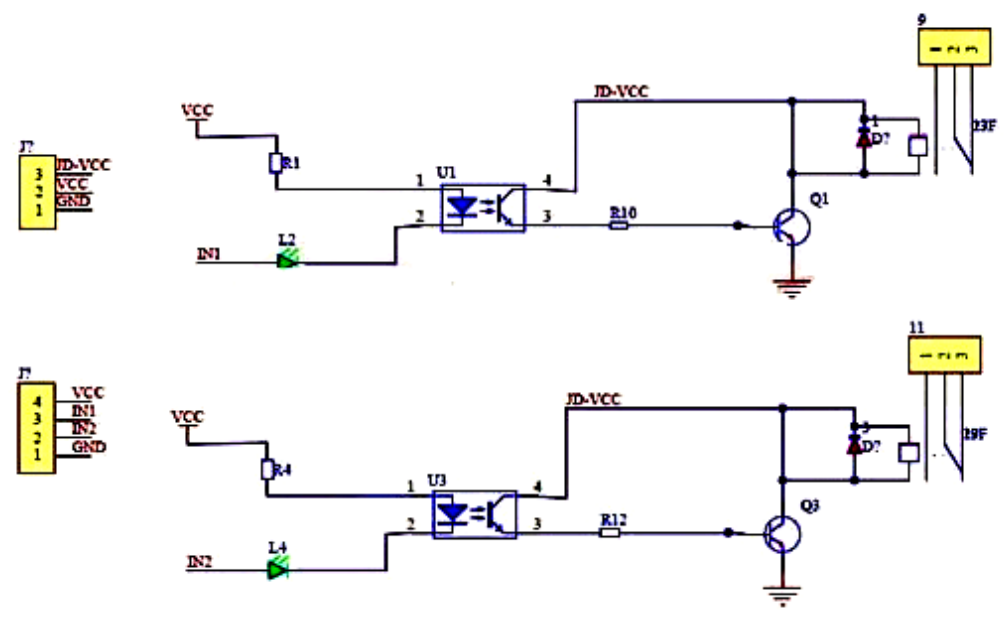

Gambar 5. Skema Modul Penggerak Motor DC

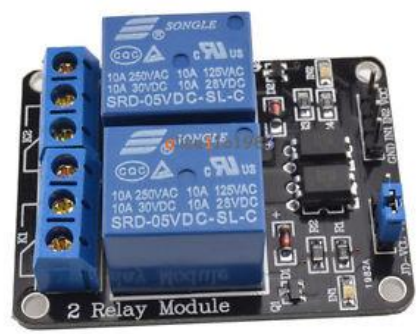

Gambar 6. Modul Penggerak Motor DC

\subsection{Sistem Perangkat Keras}

Perangkat keras terbagi atas 2 modul, yaitu Modul Master dan Modul Slave.

Modul Master menggunakan Arduino Uno R3 sebagai pusat pengontrol kerja sistem [4], Modul GPS APM 2.5 NEO 6M untuk mendapatkan data koordinat, dan Modul 433 $\mathrm{MHz}$ Radio Telemetry Kit sebagai transponder untuk melakukan komunikasi antara Modul Master dan Modul Slave. Skema Modul Master dapat dilihat pada Gambar 7. Realisasi Modul Master diperlihatkan pada Gambar 8. Tabel 1 menunjukkan koneksi Arduino Uno R3 dengan Modul GPS, Modul transponder, dan penampil LCD.

Modul Slave menggunakan Arduino Uno R3 sebagai pusat pengontrol kerja sistem dan Modul $433 \mathrm{MHz}$ Radio Telemetry Kit sebagai transponder untuk melakukan komunikasi antara Modul Master dan Modul Slave. Skema Modul Slave dapat dilihat pada Gambar 9. Realisasi Modul Master diperlihatkan pada Gambar 10. Tabel 2 menunjukkan koneksi Arduino Uno R3 dengan Modul transponder dan Modul Penggerak Motor DC. 


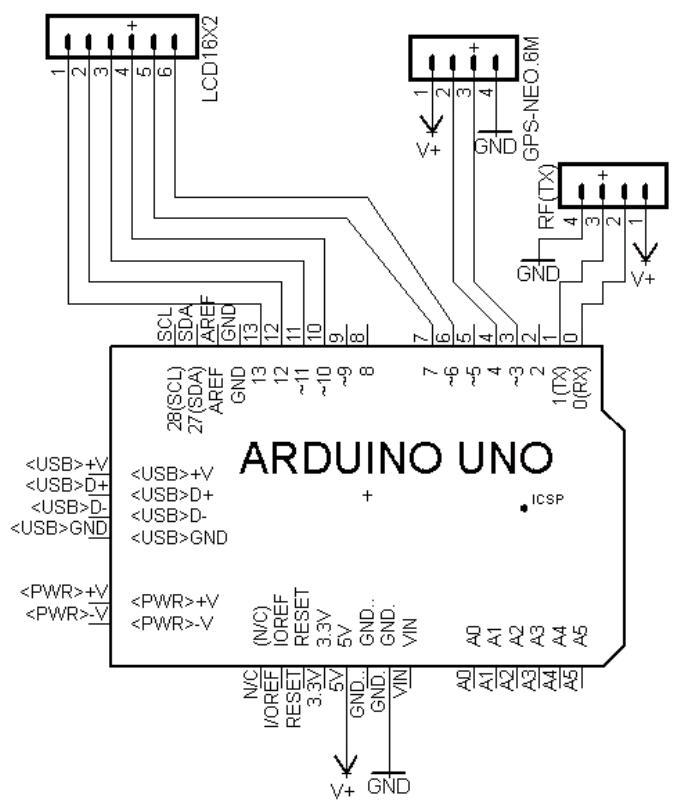

Gambar 7. Skema Modul Master

Tabel 1. Tabel koneksi Modul Master

\begin{tabular}{|c|c|}
\hline NOMOR PIN & KONEKSI \\
\hline 0 & Data Tx radio frequency \\
\hline 1 & Data Rx radio frequency \\
\hline 3 & Data RX GPS \\
\hline 4 & Data TX GPS \\
\hline 6 & Data Rs penampil LCD \\
\hline 7 & Data E penampil LCD \\
\hline 10 & Data 4 penampil LCD \\
\hline 11 & Data 5 penampil LCD \\
\hline 12 & Data 6 penampil LCD \\
\hline 13 & Data 7 penampil LCD \\
\hline
\end{tabular}

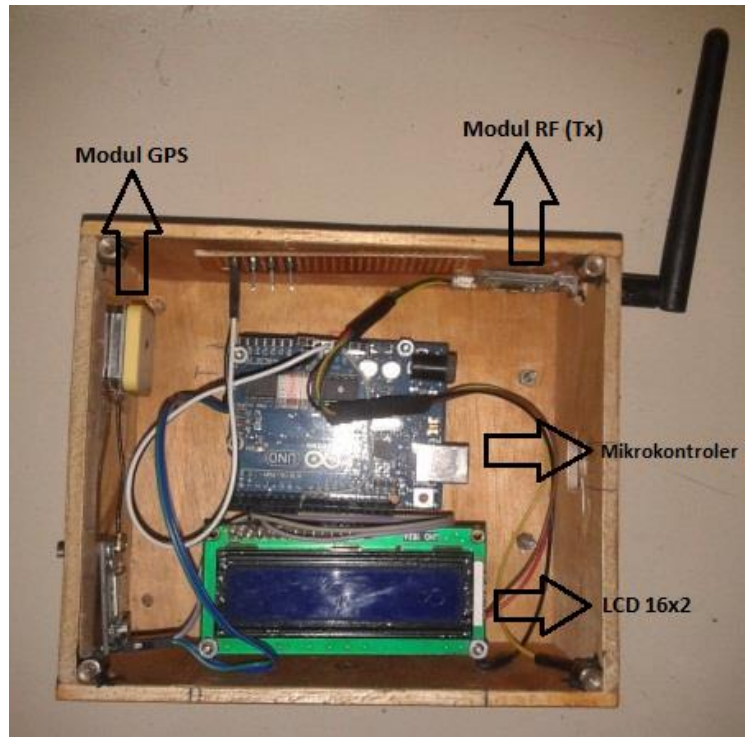

Gambar 8. Realisasi Modul Master 


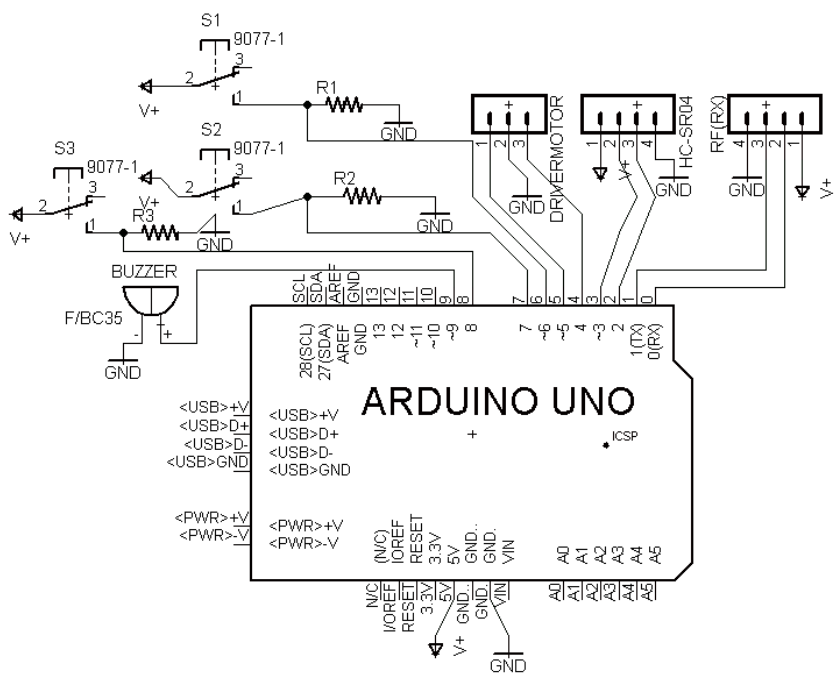

Gambar 9. Skema Modul Slave

Tabel 2. Tabel koneksi Modul Slave

\begin{tabular}{|c|c|}
\hline NOMOR PIN & KONEKSI \\
\hline 0 & Data Tx radio frequency \\
\hline 1 & Data Rx radio frequency \\
\hline 4 & Ke Masukan Penggerak Motor \\
\hline 5 & Ke Masukan Penggerak Motor \\
\hline
\end{tabular}

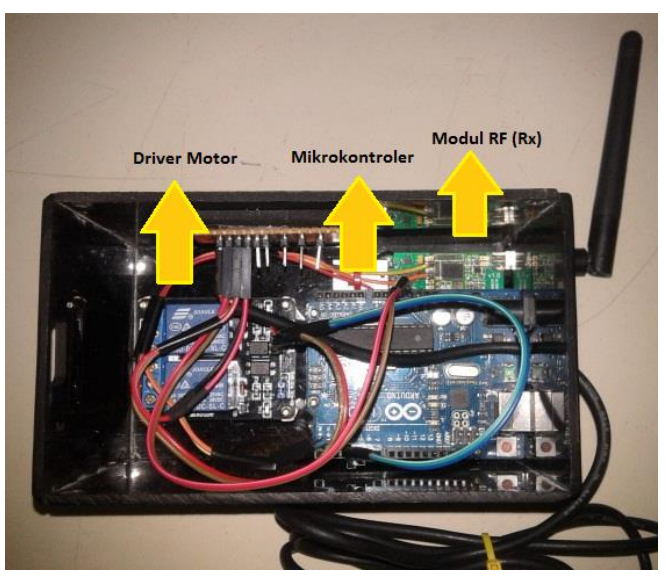

Gambar 10. Realisasi Modul Slave

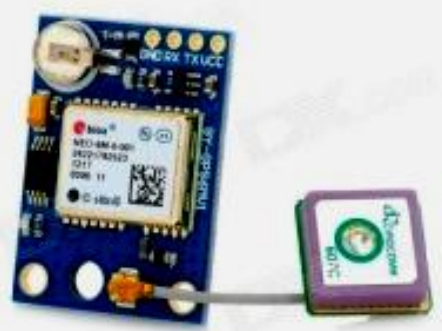

Gambar 11. Modul GPS APM 2.5 NEO 6M 


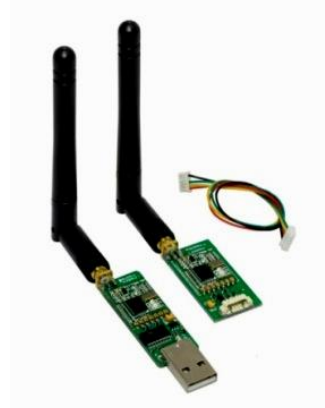

Gambar 12. Modul 433 MHz Radio Telemetry Kit

\subsection{Sistem Perangkat Lunak}

Bagan alir perangkat lunak ditunjukkan oleh Gambar 13. Perangkat lunak akan menerima data koordinat dari GPS kemudian mengolahnya untuk mengetahui jarak antara Modul Master yang ada di gerbong kereta dengan Modul Slave di perlintasan [5]. Jarak yang diperoleh ini dipakai oleh sistem sebagai dasar untuk memberikan sinyal perintah penutupan dan pembukaan palang pintu.

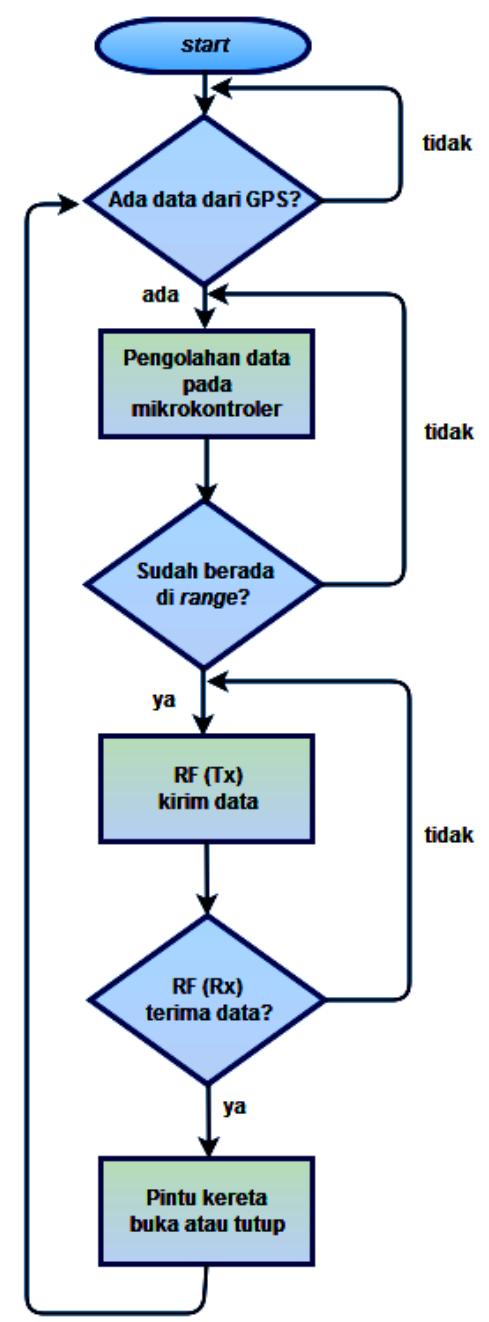

Gambar 13. Bagan alir Perangkat Lunak 


\section{Hasil Pengujian}

Pengujian Modul Master dilakukan dengan meletakkannya di dalam gerbong kereta api yang sedang berjalan. Kemudian bersama dengan Modul Slave yang ada di perlintasan diuji apakah komunikasi bisa terjadi sesuai dengan jarak yang telah direncanakan. Pengujian sistem secara keseluruhan melibatkan juga prototipe palang pintu di perlintasan.

Lokasi pengujian dilakukan di antara Stasiun Solo Balapan dan Stasiun Purwosari, Solo. Pengujian dilakukan menggunakan kereta api Prameks.

Dari hasil pengujian didapatkan bahwa pada saat gerbong kereta api dengan jarak 595m menuju perlintasan dilakukan proses penutupan palang dan setelah gerbong meninggalkan perlintasan dalam jarak 300m maka palang pintu akan membuka.
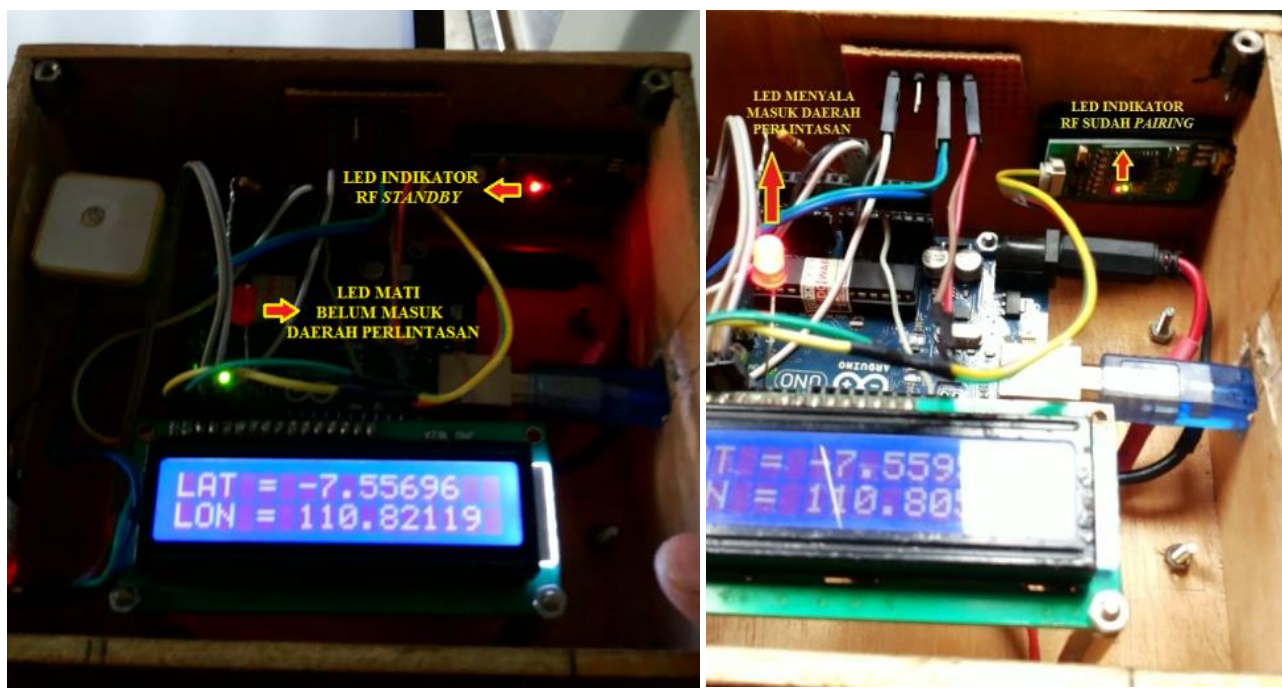

Gambar 14. Pengujian Modul Master di dalam gerbong kereta api

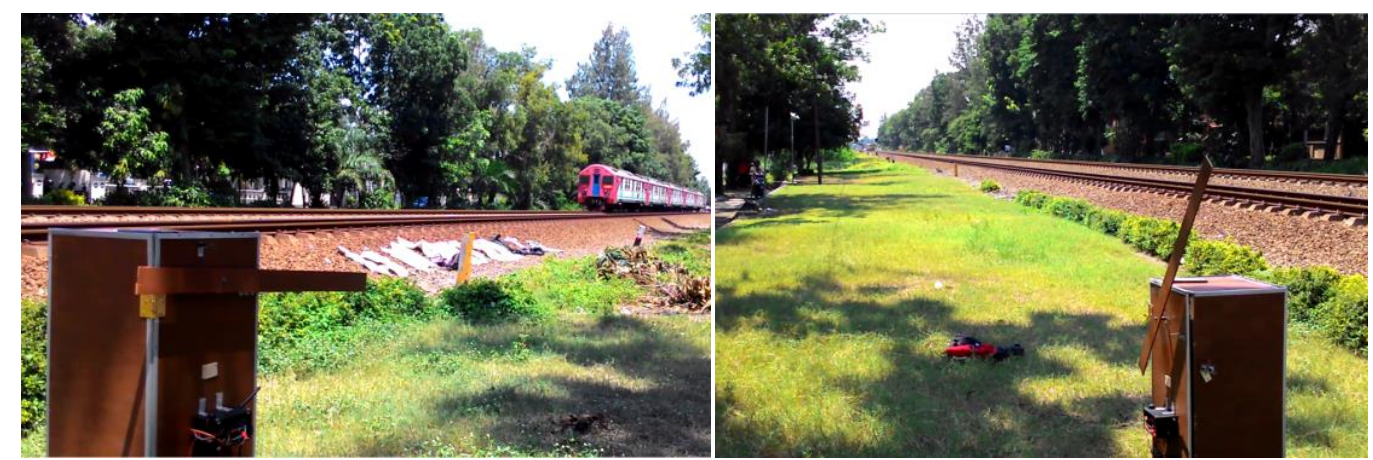

Gambar 15. Pengujian Modul Slave dan mekanik palang pintu 


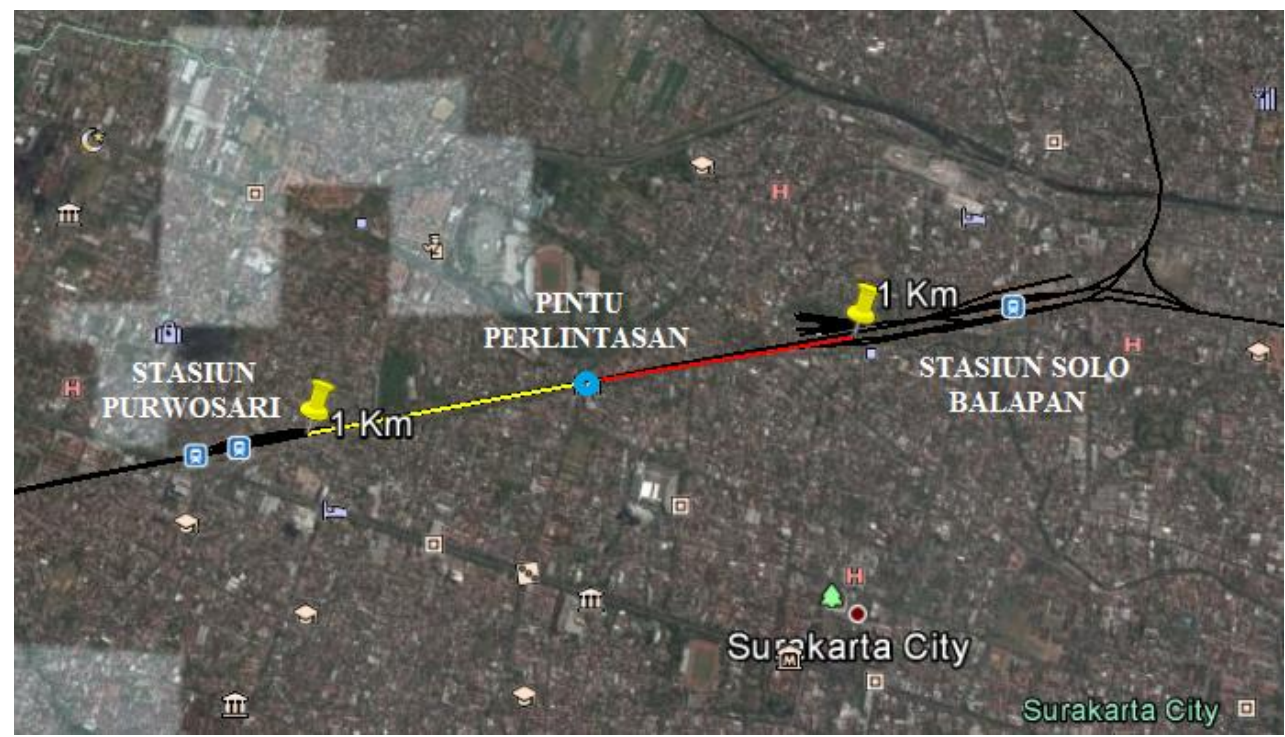

Gambar 16. Lokasi pengujian

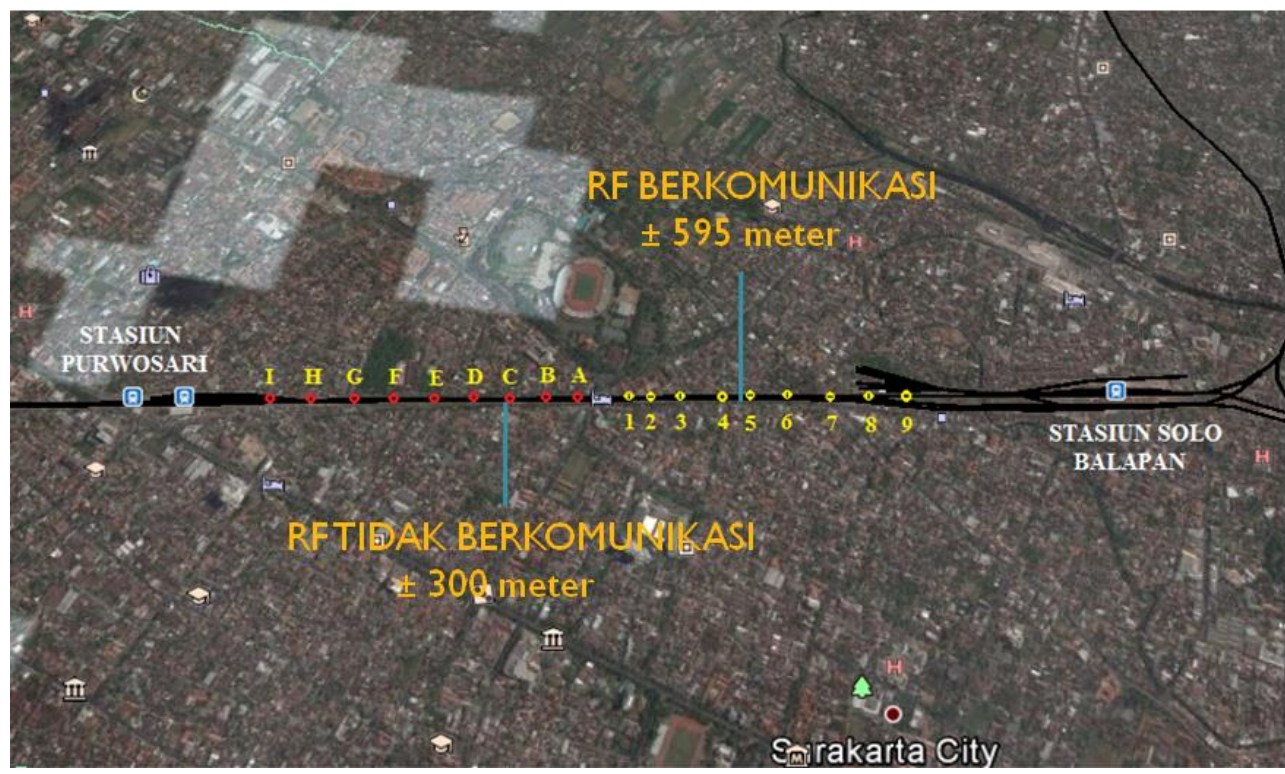

Gambar 17. Penggambaran posisi kereta api

\section{Kesimpulan}

Sistem pengontrol buka tutup palang pintu di perlintasan kereta api telah berhasil direalisasikan menggunakan perangkat Arduino Uno R3, GSM APM 2.5 NEO 6M, serta transponder $433 \mathrm{MHz}$ Radio Telemetry Kit. Sistem terdiri atas 2 bagian, yaitu Modul Master yang diletakkan di dalam gerbong kereta api dan Modul Slave yang diletakkan di perlintasan kereta api. Sistem ini tidak memerlukan penjaga palang perlintasan. Palang pintu di perlintasan akan menutup pada saat kereta api menuju perlintasan dalam jarak $595 \mathrm{~m}$ dan palang pintu akan membuka setelah gerbong kereta meninggalkan perlintasan dalam jarak $300 \mathrm{~m}$. 


\section{Daftar Pustaka}

[1] A.B. Santoso, Martinus, dan Sugiyanto, "Pembuatan otomasi pengaturan kereta api, pengereman, dan palang pintu pada rel kereta api mainan berbasis miktokontroler", Jurnal FEMA, vol. 1 no. 1, Januari 2013.

[2] A. Solichin, A. Ardiansyah, "Simulasi kendali pintu perlintasan dan pemberitahuan kedatangan kereta api otomatis menggunakan sensor optocoupler dan SMS gateway pada stasiun kereta api Kebayoran", Prosiding Seminar Nasional Ritektra, 2011.

[3] A.N.N. Chamim, "Penggunaan microntroller sebagai pendeteksi posisi dengan mengunakan sinyal GSM", Jurnal Informatika, vol. 4 no.1, Januari 2010.

[4] A.S. Zuhri, "Sistem palang pintu rel kereta api otomatis menggunakan Arduino", Tugas Akhir Jurusan Teknik Elektronika Universitas Negeri Malang, Malang: 2016.

[5] H.S. Pramono, "Pembacaan posisi koordinat dengan GPS sebagai pengendali palang pintu rel kereta api secara otomatis untuk penambahan aplikasi modul praktik mikrokontroler", Jurnal Pendidikan Teknokolgi dan Kejuruan, vol. 20 no. 2, Oktober 2011. 